\title{
Analysis of Potential Economic Sector on Gowa District, Indonesia
}

\author{
Anwar Ramli \\ Department of Management, Faculty of Economy, State University of Makassar, South Sulawesi, \\ Indonesia \\ anwar288347@yahoo.com
}

\begin{abstract}
Anwar Ramli 2014 ( Analysis Of Potential Economic Sector On Gowa District, Indonesia ) The study aims at discovering the superior sector in Gowa district and examining the economic growth in Gowa district. The study is a quantitative research with figures-based regional micro economic that verificative-quantitative in nature, which use the formula on regional economic on date of regional macro in Gowa district. Data were collected by determining the types of data adjusted with quantitative data. The measurement period used time series data with five-year period, from 2008 to 2012. Data were analyzed by employing economic analysis method, namely Location Quotient (LQ) analysis and Shift Share analysis. The results of the study reveal that the result of LQ analysis determined that the basis sectors in Gowa district were agriculture, finance, and services; the non-basis sectors were mining and quarrying sector, processing industry, electricity gas and water supply, building construction, trade, hotel and restaurant, as well as transportation and communication. The results of Shift Share analysis indicated that the sector which have rapid growth in the province level (PS+) were electricity gas and water supply, building construction, trade, transportation and communication as well as finance leasing sector. The economic sectors which have competitive superior or competitiveness (DS+) were mining, transportation and communication, as well as finance and leasing sectors.
\end{abstract}

Keywords: Potential Economic Sector, Growth,Location Quotient.

\section{INTRODUCTION}

Gowa as one of the autonomous regions that have the potential of human resources and natural resources in the province of South Sulawesi, also the authority to run the administration and development, in order to exploit the natural wealth and its other potentials, the main attention is devoted to the composition of the economy with I know a donation or contribution of each sector of the economy to the Product Domestic Regional Bruto (PDRB) because PDRB is a tool that can be used to measure the economic growth of a region.

Although the agricultural sector in Gowa still very dominant, but its contribution in 2012 was reduced by about 1.3 points compared to 2011. Meanwhile, sectors such as services and financial services companies showed an increase in contributions. This is an interesting phenomenon to be studied, because the characteristics of a developing region that is in addition to the significant economic growth, as well as a shift in the economic structure.

To determine the economic potential of a region by sector, are used to determine the contribution of each of these sectors to the PDRB and the ability of each of the sector to absorb 
labour. The sectors that contributing most capable and at the same time absorbing the highest labour, will be the leading economic potential (sector basis) area.

Therefore in carrying out development with cracked scarce, the consequences should be focused on the development of sectors that impact multiplier (multiplier effect) significantly to other sectors in the economy as a whole. So the core of this research is aimed to assess the economic potential sectors Gowa is expected to be a key driver of economic growth in this area in the future.

\section{Problem}

\section{How to shift the economic structure based on the analysis of shift share and Location Quotient?}

\section{LITERATURE}

\section{Economic Development}

Human capital accumulation has long been regarded as an important factor in economic development. The results obtained in the initial set of regression was therefore somewhat disappointing: When a person is running a Cobb-Douglas specification implied in Jess Benhabib, Mark M. Spiegel (1994) standard production function that includes human capital as a factor, human capital accumulation fails to enter significantly in the determination of economic growth, and even come in with a negative point estimate.

More and better education is a prerequisite for rapid economic development around the world. Education stimulate economic growth and improve people's lives through many channels: By increasing the efficiency of the labor force, by increasing democracy (Barro, 1997 in Thorvaldur Gylfason, 2001) and thus create better conditions for good governance, through the improvement of health, by improving equality (Aghion et al., 1999, in Thorvaldur Gylfason, 2001).

Example, or model, a successful theory is the theory of economic growth, Robert Solow and Edward Denison in (Robert E. Lucas, Jr., 1988) was developed and applied to the twentieth century US experience. This theory will serve as a basis for further discussion in three ways: as an example of the form that is useful aggregative theory should take, as an opportunity to explain what form the theory can tell us that another type theory cannot, and as a theoretical possibility for economic development.

\section{Economic Evolution}

The world economy into a seamless, integrated, driven by global market forces, the strength of the world technology, the strength of the global cost and macro political and economic power. The world economy and global competition arena is changing the way in which the company traditionally operated in Shailendrakumar Uttamrao.

From a global perspective, entrepreneurship is the backbone of our economy and our nation's mandate to wealth. It is at the core of our being. This is as well as a source of economic stability and spring also innovation. It is the uniqueness entrepreneurial authors find so appealing: its ability to deliver economic stability at the same time encouraging innovation. All this are from the dream.

Schumpeter (1942) in JoAnn and James (2004) estimate the managed economy that emerged after World War II, with their emphasis on giant corporations practicing economies of scale.

Simply reflect on what we have seen in the world to date. The whole world is shrinking we have seen the power of entrepreneurship, the true wealth of the nation. In a small, developing countries that have seen entrepreneurial take on the role of Prometheus and bring fire to fuel 
economy growth. In previously communist countries we have seen entrepreneurial take on the role of Phoenix, up the reborn from a fiery nest to revive economic well-being.

In our own history, we have seen a small band of refugees fleeing religious persecution and economic wilderness to build a nation that spans the globe with the Yankee merchant ships and grow as leaders in the Western World. We have seen a war torn, pressed from the European community to encourage their nation back from the brink of economic disaster into a dynamic, living members of a new world order. In all the stories we've ever seen on the stage of history, one thread appears in every weave, the constant appearing in each function, one aspect appears in each population: the entrepreneurial dream. Let's remove barriers to the dream and watch us bring the world to a brighter future.

Traditional economic development activities have involved local and state government employees actively soliciting and recruiting large employers by offering tax moratoriums, training and relocation assistance, infrastructure development or enhancement, or any of a number of other incentive programs or proposals. This effort is expensive and has been highly praised in the past as a major source of job growth in a country or region (JoAnn and James, 2004).

Intuition quite simple: If market finance backward, then people will choose less productive, but 'Flexible' technology. Given this technology, manufacturers not experience many risk, and therefore there is very little incentive to develop the financial markets. In contrast, when financial markets developed, technology will be special and risk, thereby creating the need for the financial markets. In terminology Cooper and John (In Gilles Saint-Paul, 1992), there complementary strategic among financial markets and technology, as both is an instrument which can be used to diversification.

\section{Reinforcement Economy}

Local economic development is a process that local governments and communities to manage resources - existing resources, by establishing a partnership between local government and the private sector to job creation, and can stimulate economic growth in relevant areas (Soeparmoko, 2002).

Since the reform era in 1999, there was a paradigm shift in the system of governance of the pattern into a pattern of centralization or decentralization called regional autonomy imply, the shift of most of the decision-making process in the planning, implementation and evaluation of the organization of the central government to the regions (Armida, 2000). Therefore development potential that each region varies, each region must determine the dominant economic sector (Syafrizal, 1997).

Local economic development is generally defined as a process that causes the per capita income of the population of a region increases over the long term (Arsyad, 1999). Local economic development is a process that includes the establishment of new institutions, the development of alternative industries, improving the capacity of the existing work to produce products and services better, identifying new markets, expert knowledge and the development of new enterprises (Arsyad, 1999).

Two conditions that affect regional development planning process is the pressure that comes from the environment in the country and abroad that affect the needs of the region in the process of economic development, the fact that the local economy of a country is influenced by each sector differently (Kuncoro, 2004).

In this connection regions have autonomous rights. Meanwhile, the regional development planning development activities, funding, and accountability is done by the centre, while the implementation could involve areas where such activity takes place (Munir, 2002). 
Regional economic activity is classified into two sectors of activity, the activity of the base and non-base. Activity is the base of export-oriented activities (goods and services) out of bounds territory's economy is concerned, while the non-base activities are locally oriented activities that provide goods and services to the needs of the people within the borders of the economy is concerned.

This theory states that determinant of economic growth of a region is directly related to the demand for goods and services from outside the area. The growth of industries that use local resources, including labor and raw materials for export, will generate local wealth and job creation (Lincoln, 1999).

The theory divides the base production / type of work contained in one area of the sector and the sector of non-base basis. Base activities are activities that are exogenous meaning not tied to the region's economy and internal conditions also functions to encourage the growth of other types of employment while non-base activities are activities to meet the needs of people in the region itself. Therefore, growth is dependent on the general economic conditions of the region. It means that the sector is endogenous (not free to grow). Its growth depends on the economic condition of the region as a whole (Tarin, 2007).

Activity base has a role as a prime mover (primary mover) in the growth of a region. The greater the export of an area to another will be more potential growth in the region, and vice versa. Any changes that occurred in the base will cause multiple effects (multiplier effect) in the regional economy (Adisasmita, 2005).

Base sector is a sector that became the backbone of the regional economy because it has a competitive advantage (Competitive Advantage) is quite high. While the sector is the basis of other sectors with less potential but serves as a support base or service sector industries (Sjafrizal, 2008). Sector economic base of a region can be analysed by techniques Location Quotient (LQ), which is a comparison of the magnitude of the role of the sector / industry in an area of the size of the role the sector / industry nationally (Tarin, 2007).

According to Glasson (1977), more and more sectors of the base in the region will increase the flow of revenue to the region, increasing the demand for goods and services in it, and give rise to the increase in volume of the non-basis. Glasson also suggests to use the location quotient method in determining whether the sector base or not. To determine whether a sector is a sector basis or non-base can be used several methods, namely the direct measurement and indirect measurement methods. Direct measurement method can be done by direct surveys to identify which sector is a sector basis.

Based on these three methods Glasson (1977) suggested the LQ method in determining the base sector. Richardson (2001) stated that the LQ technique is most commonly used in studies of empirical basis. The assumption is that if a region is specialized in producing a particular item, then the area of export goods in accordance with the level of specialization in producing goods.

According Arsyad (1999) the main problems in the area of development is the emphasis lies on the development policies based on the uniqueness of the area concerned with the potential use of human resources. This orientation leads to taking initiatives coming from the area in the development process to create new employment opportunities and stimulate economic improvement. Shift share analysis is a very useful technique to analyse changes in the economic structure of the region compared to the national economy. Therefore, if a shift differential of an industry is positive, then the industry competitiveness is higher than the same industry in the economy as the reference. (Arsyad, 1999). 
Furthermore, there are few previous studies related to this research are as by Supangkat (2002), making the analysis of sector priorities in the determination of the Regional Development Improvement Asahan District North Sumatra Province ", using PDRB-forming sector approach, found that agriculture and processing industries likely to serve as the priorities for the improvement of the construction sector in the District shavings, especially the plantation sub-sector, fisheries and large industries, as well as medium-sized industries.

Furthermore, Ebtian Rico (2011) found that the PDRB-forming sector approach, the method used is Klassen Typology, Location Quotient, and shift share analysis. Shift share analysis results indicate that the sector is a competitive sector, namely trade, hotels and restaurants, transport and communications, and the financial sector and leasing and business services.

Beni Harisman year (2007), examines the Economic Structure and Identification Sectors Featured in Lampung Province 1993-2003 period, with a shift share analysis methods found that there has been a change in the economic structure in Lampung from the primary sector to the secondary sector. This is demonstrated by the role of the secondary sector continues to increase through the contribution to PDRB of Lampung Province, followed by the primary sector, then the tertiary sector.

\section{Public Policy}

Public policy is needed, not least because: 1) Public policy is the regulation; 2) Regulation is a rule which states that the government made the organizers; 3 ) Thus, public policy is needed to set up or manage society, nation, state, in all aspects of the lives of many people's life; 4) Public policy is one tool or device that is required to achieve the objectives set by the government on behalf of the public interest.

The process of public policy, at least not to include: 1) Formulation of the problem; 2) Forecasting; 3) Recommendation; 4) Monitoring; 5) Evaluation. Innovative public policy should always be: 1) based on the public interest; 2) The planning, implementation, and monitoring and evaluation involving public participation; 3) formulation always moves dynamically in accordance with the development aspirations.

Terminology public policy (public policy) it turned out a lot, depending on the point where we perceive it. Easton provides a definition of public policy as the authoritative allocation of values for the whole society or as an allocation of values by force of the whole community 2).

Laswell and Kaplan also defines public policy as a projected program of goals, values, and practice or something achieving program goals, values in the targeted practices. Understanding public policy is expressed by Anderson stated public policy as a purposive course of action Followed by an actor on the set early actors in dealing with a problem or matter of concern or as an action that has a specific purpose that is followed and implemented by a principal or group of offenders in order to solve a problem.

Michael E. Porter in Susilawati Susy (2007) explains that the competitive advantage of each country is determined by how well the country is able to create an environment that fosters competitiveness of every actor in it. In the context of global competition, it is the task of the public sector is to build an environment that allows each development actors are able to develop to become competitive actors.

This environment can only be created effectively by public policy. Therefore, the best public policy is a policy that encourages every citizen to build competitiveness of each and not getting plunged into a pattern of dependency.

Richard Layard (2005) in the John F. Helliwell (2005) argues, the trend of short-term commitments, and increasing monetary and other awards to linking individual performance 
targets, particularly the short term, may be having a corrosive effect on trust and loyalty and create unhappiness in process. Having digested the importance of trust and involvement, they may be expected to inform virtually every policy decision regarding the form and public service.

\section{Regional Autonomy}

Etymologically, the term "autonomy" is derived from the Latin, meaning their autos and nomos meaning rule. Based on the etymology, autonomy can be defined as a set or govern themselves. Thus, the notion of autonomy is the delegation of authority and responsibility from central government to local governments. Before the implementation of regional autonomy, all local governments in Indonesia simply accept the program of the central government so that there is uniformity in each program area. However, after the introduction of regional autonomy, the region has the authority to manage their own regions.

According to Law No. 32 of 2004 on Regional Government, the notion of autonomy is an autonomous regional authority to manage and administer governmental affairs submitted by the central government and the interests of society at its own initiative based on the aspirations of the people in accordance with the legislation. The Republic of Indonesia as a unitary state adheres to the principle of decentralization in governance, by providing the opportunity and freedom to the region to conduct regional autonomy. The decentralization policy embodied in the establishment of the autonomous region and the implementation of regional autonomy is directed to accelerate the realization of public welfare.

Regional autonomy is the ability to take care primarily concerned with public administration and development, which was previously taken care of the central government. So, besides the necessary of financial capacity, it required also the presence of qualified human resources, natural resources, capital and technology (Rudini, 1995: 48 in Purbayu and Retno, 2005).

The purpose of decentralization is to improve the human resources needed in order to realize autonomy. Human resources that are needed include (Silalahi, et al, 1995: 12 in Purbayu and Retno, 2005):

- Having a container, behavioural, quality, goals and activities based on the specific expertise and skills.

- Creative in the sense of having an innovative spirit, and be able to anticipate challenges and developments, including having a high work ethic.

- Able as a driver has a non-governmental high sense of social solidarity, is sensitive to the dynamics of society, able to work together, and have thought people centered orientation.

- Having a high discipline in the sense of thinking consistent with the program, so as to describe the national policies into operational programs in accordance with the local government guidelines stipulated affairs program understanding.

To be able to realize for regional autonomy in order to have the flexibility in the implementation of regional governance, then according to Agus Shamsuddin (In Trilaksono Nugroho, 2000) associated with some of the following:

First, Self-Regulating Power is the ability to organize and implement regional autonomy for the welfare of the community.

Second, Self-Modifying Power is the ability to make adjustments on the nationally established rules to local conditions.

Third, Local Political Support, which held that local government has a broad legitimacy of the public, both in the position of Regional Head as executive element maupu Parliament as the 
legislative bodies. Support local political will at the same time ensuring the effectiveness of governance and development.

Fourth, the Financial Resources is namely to develop skills in managing resources and sufficient financial income to finance the activities of governance, development and community service which soon became his needs.

Fifth, Developing Brain Power, which is building the human resources of the government apparatus and reliable society that rest on the intellectual capability in solving various problems. As the implications of this conceptual framework, the things that is fundamental of the Act No. 22, 1999 which is not found on the previous laws governing the Local Government (Law No. 5 of 1974).

\section{METHODS}

This research is a quantitative micro-regional economies located in Gowa. This is a descriptive analytical study that describes the level of each sector potential that would be useful for improving the competitiveness of the sector. The data analysis technique used in this study is analysis of Location Quotient (LQ) is used to determine the base and non-base sectors in the economy of the region Gowa. LQ method used to assess the condition of the economy, leading to the identification of specialization of economic activities.

\section{DISCUSSION}

\section{The shift in the economic structure based on the analysis of shift share and Location Quotient?}

Gowa PDRB growth during 2008-2012 with the details of the increase in the percentage of each field of business / economic sectors as follows:

\begin{tabular}{|c|c|c|c|c|c|}
\hline Business Sector & $\mathbf{2 0 0 8}$ & $\mathbf{2 0 0 9}$ & $\mathbf{2 0 1 0}$ & $\mathbf{2 0 1 1}$ & $\mathbf{2 0 1 2}$ \\
\hline Agriculture & 5,15 & 5.23 & 3,19 & 3.20 & 4,01 \\
\hline Mining / Quarrying & 10.66 & 15,10 & 12.74 & 17.46 & 16.39 \\
\hline Manufacturing & 7.17 & 5.93 & 6.23 & 6,65 & 6.85 \\
\hline Electricity, Gas and Water & 7.08 & 7.32 & 7.98 & 8,16 & 9,13 \\
\hline Building & 8,66 & 9.40 & 10,13 & 9,95 & 12,90 \\
\hline $\begin{array}{c}\text { Trade Hotel and } \\
\text { Restaurants }\end{array}$ & 9.42 & 10.29 & 9.87 & 9.72 & 10,45 \\
\hline $\begin{array}{c}\text { Transportation and } \\
\text { Communications }\end{array}$ & 11.69 & 15,19 & 15.81 & 10,50 & 12,90 \\
\hline $\begin{array}{c}\text { Financial, Leasing \& } \\
\text { Services Company }\end{array}$ & 12.5 & 15.12 & 11.0 & 15.0 & 18.65 \\
\hline Services & 5.61 & 8,32 & 3,60 & 3,82 & 2,94 \\
\hline PDRB & 6.92 & 7,99 & 6,05 & 6,20 & 7,28 \\
\hline
\end{tabular}

Source: BPS Gowa district

In Table 2 portray Gowa district PDRB growth during 2006-2012 with the details of the increase in the percentage contribution of each business field / sector of the economy to the economic structure of Gowa. It can be seen that the percentage of the agricultural sector annually decreased inversely related to mining / multiplication and finance, leasing and corporate services. While the services sector showed an increasing trend was good although in 2010 the services sector decreased from the previous contributions in 2009 amounted to 21.80 per cent decreased to 21.74 percent in 2010 , but increased again in the next year. 
Table 3: Economic Structure Gowa Year 2006-2012 (Percent)

\begin{tabular}{|c|c|c|c|c|c|c|c|}
\hline Business Sector & $\mathbf{2 0 0 6}$ & $\mathbf{2 0 0 7}$ & $\mathbf{2 0 0 8}$ & $\mathbf{2 0 0 9}$ & $\mathbf{2 0 1 0}$ & $\mathbf{2 0 1 1}$ & $\mathbf{2 0 1 2}$ \\
\hline Agriculture & 51.48 & 50.85 & 48.78 & 45.65 & 44.61 & 43.31 & 41.44 \\
\hline Mining / Quarrying & 0,62 & 0,63 & 0,63 & 0,64 & 0,67 & 0,72 & 0,77 \\
\hline Manufacturing & 3,34 & 3,31 & 3,19 & 3,05 & 3,08 & 3,07 & 3,06 \\
\hline $\begin{array}{c}\text { Electricity, Gas and } \\
\text { Water }\end{array}$ & 1.74 & 1,73 & 1,66 & 1,56 & 1,55 & 1.52 & 151 \\
\hline Building & 2,49 & 2,50 & 2,43 & 2,35 & 2,42 & 2.47 & 2,62 \\
\hline $\begin{array}{c}\text { Trade Hotel and } \\
\text { Restaurants }\end{array}$ & 13.40 & 13.61 & 13.48 & 13.35 & 13.87 & 14.22 & 14.79 \\
\hline $\begin{array}{c}\text { Transportation and } \\
\text { Communications }\end{array}$ & 5,77 & 5.89 & 5,85 & 5,76 & 6,00 & 5.98 & 6,26 \\
\hline $\begin{array}{c}\text { Finance, Real Estate } \\
\text { \& Business Services }\end{array}$ & 5,15 & 5,47 & 5,68 & 5,84 & 6,05 & 6.53 & 6,99 \\
\hline Services & 16,02 & 16,02 & 18,32 & 21.80 & 21.74 & 22.19 & 22.56 \\
\hline PDRB & 100.0 & 100.0 & 100.0 & 100.0 & 100.0 & 100.0 & 100.0 \\
\hline
\end{tabular}

Source: BPS Gowa district

\section{Location Quotient (LQ)}

Location Quotient (LQ) is used to determine the economic sectors in PDRB that can be classified into base and non-base sectors. LQ is a comparison of the magnitude of the role of the sector in Gowa to the role of the sector at the level of South Sulawesi Province.

Table 4: Results of Analysis of LQ Gowa 2008-2012

\begin{tabular}{|c|c|c|c|c|c|c|c|}
\hline Business Sector & $\mathbf{2 0 0 8}$ & $\mathbf{2 0 0 9}$ & $\mathbf{2 0 1 0}$ & $\mathbf{2 0 1 1}$ & $\mathbf{2 0 1 2}$ & Median & $\begin{array}{c}\text { Classification of } \\
\text { sectors }\end{array}$ \\
\hline Agriculture & 1.65 & 1.63 & 1.68 & 1.65 & 1.65 & 1.65 & Base \\
\hline Mining / Quarrying & $0: 06$ & $0: 07$ & $0: 07$ & $0: 10$ & $0: 11$ & $0: 08$ & Non-base \\
\hline Manufacturing & $0: 28$ & $0: 28$ & $0: 29$ & $0: 29$ & $0: 28$ & $0: 28$ & Non-base \\
\hline Electricity, Gas and Water & 0.96 & 0.94 & 0.95 & 0.96 & 0.94 & 0.95 & Non-base \\
\hline Building & $0: 59$ & $0: 56$ & $0: 57$ & $0: 57$ & $0: 58$ & $0: 57$ & Non-base \\
\hline Trade Hotel and Restaurants & 0.87 & 0.85 & 0.85 & 0.86 & 0.87 & 0.86 & Non-base \\
\hline $\begin{array}{c}\text { Transportation and } \\
\text { Communications }\end{array}$ & 0.75 & 0.77 & 0.79 & 0.79 & 0.79 & 0.78 & Non-base \\
\hline $\begin{array}{c}\text { Financial, Leasing \& Services } \\
\text { Company }\end{array}$ & $1: 11$ & $1: 13$ & $1: 09$ & $1: 11$ & $1: 15$ & $1: 12$ & Base \\
\hline Services & $1: 47$ & $1: 48$ & $1: 50$ & $1: 48$ & $1: 50$ & $1: 49$ & Base \\
\hline
\end{tabular}

Source: Data processed

Sector which is the sector base or leading sectors namely agriculture, finance and leasing, and Services sectors. While the mining sector, the manufacturing sector, the power sector gas and water, construction, trade hotels restaurants, and transport and communications sector, a sector or a non-base instead of leading sectors. The mining sector is the sector with the lowest LQ is equal to 0.08 . Trade sector's restaurant shows LQ of 0.86 . The electricity gas and water supply showed LQ 0.95 . Manufacturing sector shows 0.28 . Transport and communications sector amounted to 0.78 . Construction sector shows 0.57 . This means that these sectors cannot meet the demand in Gowa district.

\section{Shift Share Analysis}

Shift Share Analysis is used to determine the economic growth process Gowa linked to the regional economy as a reference, namely South Sulawesi Province. Shift Share Analysis in this study using a variable income that is PDRB growth to elaborate Gowa. 
Based on Shift-Share analysis results in Table 5 in 2008-2012, PDRB is changing in Gowa reached 503,019.21 million rupiahs. These changes are caused by factors of PDRB growth in South Sulawesi 561,549.50 million rupiahs. This means that PDRB growth is still highly dependent Gowa in South Sulawesi by the economy.

Table 5: Changes in Sectoral and Economy Affecting Component Gowa 2008-2012 (millions of rupiahs)

\begin{tabular}{|c|c|c|c|c|c|}
\hline No. & Business Sector & $\begin{array}{c}\text { Regional } \\
\text { Change }\end{array}$ & $\begin{array}{c}\text { Provincial } \\
\text { Share }\end{array}$ & $\begin{array}{c}\text { Proportional } \\
\text { Shift }\end{array}$ & $\begin{array}{c}\text { Shift } \\
\text { Differential }\end{array}$ \\
\hline One & Agriculture & $130,856.60$ & $269,108.35$ & $(111,811.88)$ & $(26,439.87)$ \\
\hline 2 & Mining & $7,316.02$ & $3,216.80$ & $(2,709.56)$ & $6,808.78$ \\
\hline 3 & Manufacturing & $18,287.81$ & $22,034.21$ & $(2,925.04)$ & $(821.36)$ \\
\hline 4 & Electricity, Gas and Water & $5,922.89$ & $5,477.86$ & $1,536.58$ & $(1,091.55)$ \\
\hline 5 & Building & $25,178.15$ & $17,286.97$ & $11,300.39$ & $(3,409.21)$ \\
\hline 6 & Trade, Hotels and Restaurants & $105,857.11$ & $76,903.24$ & $37,822.33$ & $(8,868.46)$ \\
\hline 7 & Transportation and & $67,448.50$ & $34,561.27$ & $29,366.71$ & $3,520.52$ \\
\hline 8 & Communications & $87,791.36$ & $40,177.34$ & $45,804.91$ & $1,809.11$ \\
\hline 9 & Finance and Leasing & $54,360.78$ & $92,783.47$ & $(35,289.80)$ & $(3,132.89)$ \\
\hline & Services & $503,019.21$ & $561,549.50$ & $(26,905.36)$ & $(31,624.93)$ \\
\hline
\end{tabular}

Source: Data processed

Table 5 shows that the influence of national and provincial policies in the agricultural sector is very large. While the economic condition of the structure at the provincial level, a negative effect on output growth sectors of the economy in the agricultural sector Gowa. The mining sector has a slower growth compared to the same sector in the province of South Sulawesi but this sector has the ability to compete with other regions in the same sector.

The manufacturing sector growth is sluggish compared to the sector same at the provincial level and the industry sector does not have the ability to compete with other regions. The electricity gas and water has a fairly rapid growth compared to the same sector at the provincial level but these sectors are less able to compete with the same sector in other regions.

Then the hotel and restaurant trade, growing faster than the same sectors at the provincial level but the sector is not competitive against other areas with the same sector. Transport and communications sector is also experiencing growth in output, but the effect on the growth of provincial output of this sector while the industry mix factors also have a positive impact on output growth in the transport sector. For finance and leasing sector grew faster than the same sectors at the provincial level and the sector has a fairly strong competitiveness against other regions in the same sector. Service sector output growth.

Based on the results of the calculation of the shift share analysis, which includes developing the sector in accordance with Gowa in South Sulawesi (industrial mix), which are electricity, gas and water, construction, trade, transport and communications sector, and the financial sector. The sectors that are not appropriated namely agriculture, mining, industry and services sector. The sectors that is competitive in Gowa namely mining, transport and communications, as well as the financial sector leasing while that is not competitive, namely agriculture, manufacturing, electricity gas and water, construction, trade, and services sectors.

Based on the results of the calculation of net shift (net shift) which is the sum of the proportional shift and shift differential, can be seen in Table 6 below: 
Table 6: Analysis of the Shift Share Shifts Net (millions of rupiahs)

\begin{tabular}{|c|c|c|c|c|}
\hline No. & FIELD OF BUSINESS & $\begin{array}{c}\text { Proportional } \\
\text { SHIFT }\end{array}$ & $\begin{array}{c}\text { SHIFT } \\
\text { DIFFERENTIAL }\end{array}$ & NET SHIFT \\
\hline One & Agriculture & $(111,811.88)$ & $(26,439.87)$ & $(138,251.75)$ \\
\hline 2 & Mining and Quarrying & $(2,709.56)$ & $6,808.78$ & $4,099.23$ \\
\hline 3 & Manufacturing & $(2,925.04)$ & $(821.36)$ & $(3,746.40)$ \\
\hline 4 & Electricity, Gas and Water Supply & $1,536.58$ & $(1,091.55)$ & 445.03 \\
\hline 5 & Building & $11,300.39$ & $(3,409.21)$ & $7,891.17$ \\
\hline 6 & Trade, Hotels and Restaurants & $37,822.33$ & $(8,868.46)$ & $28,953.87$ \\
\hline 7 & $\begin{array}{c}\text { Transportation and } \\
\text { Communications }\end{array}$ & $29,366.71$ & $3,520.52$ & $32,887.24$ \\
\hline 8 & $\begin{array}{c}\text { Finance, Real Estate and Business } \\
\text { Services }\end{array}$ & $45,804.91$ & $1,809.11$ & $47,614.02$ \\
\hline 9 & Services & $(35,289.80)$ & $(3,132.89)$ & $(38,422.69)$ \\
\hline & TOTAL & $(26,905.36)$ & $(31,624.93)$ & $(58,530.29)$ \\
\hline
\end{tabular}

Source: Data processed

By sector in Table 6, a sector that has a value of $\mathrm{PB}>0$, namely mining and quarrying, electricity, gas and water beverages, construction, trade, transport and communication, finance and leasing. It means that the sector is a sector that is progressive or potential. While the sector has a value of $\mathrm{PB}<0$ is the sector of agriculture, manufacturing and services sector. This means that these sectors including sectors slow.

\section{Quadrant Analysis}

By looking at the value of PS and DS, it is a sector / area can be grouped into four quadrants / group.

Table 7: Position Sector Based Approaches PS and DS

\begin{tabular}{|c|c|c|}
\hline \multirow{2}{*}{$\begin{array}{l}\text { Shift } \\
\text { Differential } \\
\text { (DS) }\end{array}$} & \multicolumn{2}{|r|}{ Proportional Shift (PS) } \\
\hline & Negative (-) & Positive $(+)$ \\
\hline \multirow[t]{2}{*}{ Positive $(+)$} & $\begin{array}{l}\text { Quadrant IV: tend potential } \\
\text { (Highly potential) }\end{array}$ & $\begin{array}{l}\text { Quadrant I:Rapid Growth } \\
\text { (Fast Growing) }\end{array}$ \\
\hline & $\begin{array}{l}\text { Mining and } \\
\text { quarrying }\end{array}$ & $\begin{array}{ll} & \text { Transport and communication sector } \\
\text { - } & \text { Financial Sector, leasing and corporate } \\
\text { services }\end{array}$ \\
\hline \multirow[t]{2}{*}{ Negative (-) } & $\begin{array}{l}\text { Quadrant III: Retarded } \\
\text { (Depressed) }\end{array}$ & $\begin{array}{l}\text { Quadrant II: Thrive } \\
\text { (Developing) }\end{array}$ \\
\hline & \begin{tabular}{ll|}
- & Agricultural Sector \\
- & Industrial Sector \\
- & Services Sector \\
\end{tabular} & $\begin{array}{ll}\text { - } & \text { Electricity gas and water sectors drinking } \\
\text { - } & \text { Building Sector } \\
\text { - } & \text { Sector Trade, Hotels and Restaurants } \\
\end{array}$ \\
\hline
\end{tabular}

Source of data processed

Quadrant Analysis Based on Table 7, there are two sectors which occupies the first quadrant (positive PS and DS), the transport and communications sector and the financial sector leasing and business services. That means, these two sectors have very rapid growth (rapid growth industry).

Quadrant II (PS positive and negative DS) is occupied by three sectors, namely electricity water gas sector, construction, trade, hotels and restaurants sector. That means, these three sectors are in the depressed position but developing (developing depressed region). These sectors are 
considered to have a rapid growth rate, but the sector cannot compete with other sectors of the economy of the region (low competitiveness).

In quadrant III (PS and DS negative), there are three sectors, namely agriculture, manufacturing, and services sectors. This means that the sector has a growth rate that is depressed and not competitive (depressed region).

In quadrant IV (PS negative and positive DS), there is one sector that is mining and quarrying. This means that these sectors have a tendency as a depressed sector but potentially (highly potential). These sectors have a high level of competitiveness, but the rate of growth is slow.

\section{Table 8: Summary of Results of Analysis}

Sector base in Gowa namely agriculture, finance, and services while the non-base sectors namely mining and quarrying, manufacturing, electricity gas and water, construction, trade, hotels and restaurants, and transport and communications sectors.

Sectors that have rapid growth at the provincial level (PS +) sector, namely electricity, gas and drinking water, construction, trade, transport and communications sector, as well as finance and leasing sector. The economic sectors that have competitive advantage or competitiveness (DS +), namely mining, transport and communications sector, as well as finance and leasing sector. Sectors that have progressive growth $(\mathrm{PB}+)$ is the mining, electricity, gas and water, construction, trade, transport and communications, and finance and leasing sector.

The sector that has four advantages as well there is only one sector namely finance, leasing and corporate services. Sector that has three advantages namely the transport and communications sectors. Sector which has two advantages namely mining and multiplication, gas and electricity sectors of drinking water, construction, and trade, hotel and restaurant. Sector that has one advantage is agriculture.

\section{CONCLUSION}

Financial sector development, leasing and business services which are the dominant sector, have a high competitiveness, and classified as progressive sectors in Gowa. In addition, the agricultural sector is also one of the sectors that need to remain a concern because it is one sector which is a sector basis, although not in the fast-growing sector and highly competitive, but the agricultural sector is a sector that contributes the most high percentage compared to other sectors.

Based on the analysis of shift share the results and discussion, where there has been a change in the economic structure of the primary sector to the secondary sector, the government should pay attention Gowa and develop the secondary sector, especially electricity, gas, and water through improved public services and infrastructure with the addition of facilities and infrastructure.

\section{Reference}

Adisasmita, R, 2005. Dasar-Dasar Ekonomi Wilayah, Graha Ilmu, Yogyakarta.

Alisjahbana, Armida, 2000. Desentralisasi Fiskal dan Kebijakan Pembangunan Ekonomi Daerah. Kongres ISEI XIV Makassar.

Arsyad, Lincolin, 1999. Pengantar Perencanaan dan Pembangunan Ekonomi Daerah. BPFE, Yogyakarta.

Badan Pusat Statistik, 2012. Gowa dalam Angka 2012.

Badan Pusat Statistik, 2013. Gowa dalam Angka 2013.

Badan Pusat Statistik, 2013. Indikator Ekonomi Kabupaten Gowa Tahun 2013.

Badan Pusat Statistik, 2012. Produk Domestik Regional Bruto Kabupaten Gowa Tahun 2011. 
Badan Pusat Statistik, 2013. Produk Domestik Regional Bruto Kabupaten Gowa Tahun 2012.

Badan Pusat Statistik, 2013. Produk Domestik Regional Bruto Sulawesi Selatan Tahun 2012.

Ebtian, Rico 2011. Analisis Sektor dan Komoditi Unggulan Daerah Kabupaten Serdang Bedagai.Tesis.Pasca Sarjana USU, Medan.

Gilles Saint-Paul (1992), "Technological Choice, Financial Markets and Economic Development", European Economic Review 34 (1992) 763-781. North

Glasson, John, 1977, Pengantar Perencanaan Regional, Terjemahan Paul Sitohang, Lembaga Penerbit FE UI, Jakarta.

Harisman, Beni. 2007. Analisis Struktur Ekonomi dan Identifikasi Sektor sektor Unggula di Provinsi Lampung (periode 1993-2003).

Jhingan, M, L, 2012, Ekonomi Pembangunan dan Perencanaan, Terjemahan D.Guritno. PT. Rajagrafindo Persada, Jakarta.

John F. Helliwell (2005), “Well-Being, Social Capital and Public Policy: What's New?”, National Bureau of Economic Research 2005.

Jess Benhabib, Mark M. Spiegel (1994), "The role of human capital in economic development Evidence from aggregate cross-country data", Journal of Monetary Economics 34 (1994).

JoAnn C. Carland dan James W. Carland (2004), "Economic Development: Changing the Policy to Support Entrepreneurship", Academy of Entrepreneurship Journal, Volume 10, Number 2, 2004.

Kuncoro, M, 2004. Otonomi dan Pembangunan Daerah: Reformasi, Peremcanaan, Strategi dan Peluang. Erlangga, Jakarta.

Munir, Badrul. 2002. Perencanaan Pembangunan Daerah Dalam Prespektif Otonomi Daerah, Edisi Pertama, Bappeda Provinsi NTB, Mataram

Nadira, ST. 2012. Analisis Struktur Ekonomi dan Sektor Unggulan Kabupaten Mamuju Sulawesi Barat Periode 20042009. Skripsi. Fakultas Ekonomi UNHAS, Makassar.

Purbayu dan Retno (2005), “Analisis Pendapatan Asli Daerah (PAD) dan Faktor-Faktor Yang Mempengaruhinya Dalam Upaya Pelaksanaan Otonomi Daerah di Kabupaten Kediri”, Vol. 2 No. 1 / lull 2005: 9 - 18.

Robert E. Lucas, Jr. (1988), “On the Mechanics of Economic Development”, Journal of Monetary Economics 22 (1988) 3-42. North-Holland.

Richardson, Harry W, 2001. Dasar-Dasar Ilmu Ekonomi Regional, Terjemahan Paul Sitohang, Edisi Revisi, Lembaga Penerbit FE UI, Jakarta.

Soeparmoko, 2002. Ekonomi Publuk untuk Keuangan dan Pemerintah Daerah. Yogyakarta.andi offset.

Sore, Syafaruddin, 2011. Analisis Potensi Sektoral Di Kabupaten Pangkajene Kepulauan. Tesis. Program Pascasarjana UNM, Makassar.

Sukirno, Sadono, 1985. Ekonomi Pembangunan: Proses, Masalah dan Dasar Kebijakan, LPFE-UI, Jakarta.

Sukirno, Sadono. 1994. Pengantar Teori Makro Ekonomi. Jakarta: PT Raja Grafindo Persada.

Supangkat, 2002. Analisis Penentuan Sektor Prioritas dalam Peningkatan Pembangunan Daerah Kabupaten Asahan.Tesis. Program Pascasarjana USU, Medan.

Syafrizal, 1997. Pertumbuhan Ekonomi dan Ketimpangan Regional Wilayah Indonesia Bagian Barat. Prisma. LP3ES No.3 Tahun XXVI. Jakarta

Susy Susilawati (2007), “Analisis Kebijakan Publik Bidang Keselamatan dan Kesehatan Kerja Di Kota Tasikmalaya”, Tesis, Magister Ilmu Kesehatan Masyarakat Universitas Diponegoro Semarang 2007.

Tarigan, Robinson, 2007. Ekonomi Regional, Teori dan Aplikasi, PT. Bumi Aksara, Cetakan Keempat, Jakarta. 
2010, Pedoman Penulisan Tesis dan Disertasi, Badan Penerbit UNM Edisi Ketiga, Makassar.

Thorvaldur Gylfason (2001), "Natural resources, education, and economic development", European Economic Review (2001).

Trilaksono Nugroho (2000), "Reformasi Dan Reorientasi Kebijakan Otonomi Daerah Dalam Perspektif Hubungan Pemerintah Pusat-Daerah", Jurnal Administrasi Negara, Vol. I, No. 1, September 2000: 11-18. 